\title{
A note on prediction of maize stover quality by near-infrared reflectance spectroscopy (NIRS) technique
}

\author{
Elena Albanell ${ }^{1}$, Josefina Plaixats ${ }^{1}$ and $\mathbf{M}^{\mathrm{a}}$ Teresa $_{\mathbf{M a s}^{2}}$ \\ ${ }^{1}$ Agriculture Veterinary Department, Autonomic University of Barcelona \\ 08193 Bellaterra, Spain \\ ${ }^{2}$ Higher School of Agriculture \\ Urgell 187,08036 Barcelona, Spain
}

(Received 6 June 1997; accepted 24 October 1997)

\begin{abstract}
Near-infrared reflectance spectroscopy (NIRS) technique was investigated as a means of predicting quality parameters in semi-exotic maize stover. These parameters included neutral detergent fibre (NDF) and in vitro dry matter (DM) digestibility. Samples of semi-exotic maize stover were formed by crossing the exotic material Across 8443 La Posta with inbred Mo 17.

An InfraAlyzer 450 (Bran + Luebbe) was used for the study. Calibration equations were obtained by multiple linear regression from 162 samples and verified with 18 additional samples. The coeffcients of multiple correlation obtained were 0.92 for NDF and 0.93 for DM digestibility and the standard errors of calibration were 1.30 and 2.56 , respectively. The study showed sufficient accuracy in the prediction of NDF and digestible DM content in semi-exotic maize stover for use in the plant breeding programme.
\end{abstract}

KEY WORDS: NIRS, semi-exotic maize, NDF, DM digestibility

\section{INTRODUCTION}

Maize is generally valued as a grain crop, however it has substantial importance as a forage crop in many maize-growing regions where many hectares of maize silage are harvested annually. Whole-plant digestibility is

\footnotetext{
'Corresponding author: Elena Albanell. Agriculture Veterinary Department, Autonomic University of Barcelona
} 
influenced by two independent factors: whole-plant grain content and stover digestibility (Deinum and Bakker, 1981; Hunt et al., 1992). Hunt et al. (1992) evaluated commercial maize hybrids to determine the extent of variation for nutritional quality and found differences among commercial hybrids for both stover and whole-plant tissues. Hybrids with equal grain yield can have large differences in nutritive value. Therefore, selection criteria for silage hybrids should include whole-plant grain content and stover fibre content.

Semi-exotic populations of maize with late maturity can be obtained by crossing exotic germplasm with adapted inbred lines. Being very productive, these populations give an appropriate starting point for Mediterranean-type conditions. This material is intended for use as forage maximization of ear yields is still a goal. Therefore selection for high stover digestibility, high cell wall digestibility and low neutral detergent fibre (NDF) are important in a strategy for improving the nutritive value of the plant.

Near-infrared reflectance spectroscopy (NIRS) measurement can be used to predict nutritive quality. The application of this technique to asses quality in forage crops was first described by Norris et al. (1976). In maize (Zea mays L.), NIRS has been proposed as a tool for the prediction the nutritive value of the forage in breeding programmes (Melchinger et al., 1986; Pinter et al., 1986; Valdes et al., 1987a; Zimmer et al., 1990), because it is rapid, reliable, non-time consuming and economic, needs no chemical reagents, and multiple analyses can be conducted simultaneously.

The general objectives of this genetic study of the semi-exotic population are to estimate the values of narrow sense hereditability of many forage traits (related to maturity, whole plant production, and nutritive value of the stover) and the additive genetic correlations between them. To obtain the calibration equations of NDF content and DM digestibility of semi-exotic maize stover is the main objective of the present work. Preliminary results on stover quality traits have been published elsewhere (Albanell et al.,1995).

\section{MATERIAL AND METHODS}

\section{Sample collection and preparation}

The semi-exotic populations were formed by crossing the pure line Mol 7 with the exotic Across 8443 La Posta. The semi-exotic population (F3) was studied using a nested mating design (North Carolina I), with 50 half-sibs and 150 full-sibs (three full-sibs into each half-sib familily).

The field experiment was conducted in 1993 under irrigation, using a randomized complete block design with three replications and a density of 60.000 
$\mathrm{pl} / \mathrm{ha}$. Plants were harvested (separating the stover from the ear) when the mean grain moisture was approximately $400 \mathrm{~g} / \mathrm{kg}$. The samples were dried at $60^{\circ} \mathrm{C}$ for $48 \mathrm{~h}$ and ground through a mill fitted with a $1 \mathrm{~mm}$ screen.

\section{Chemical analysis}

Samples of maize stover were analyzed in duplicate. Dry matter was determined by drying in a forced-draught oven at $103 \pm 1^{\circ} \mathrm{C}$ for $24 \mathrm{~h}$, NDF by the method of Goering and Van Soest (1970) and in vitro DM digestibility (IVDMD) was determined using the enzymatic method of Aufrère (1982).

\section{NIRS analysis}

The NIRS equipment used in this study consisted of an InfraAlyzer 450 fitted with 19 discrete filters (Bran + Luebbe, Norderstedt, Germany) interfaced to a personal computer. Reflectance data were collected in the form of $\log (1 / R)$ (where R measures reflectance) and used to perform statistical analysis for developing the NIRS calibrations. The software for scanning, mathematical processing and statistical analysis was supplied with the spectrophotometer (IACAL P01, 1987, Bran + Luebbe, Norderstedt, Germany). The methodology for the development of NIRS equations has been given elsewhere (Albanell et al., 1993, 1995).

Eighty samples of semi-exotic maize stover used in a previous calibration (Albanell et al., 1995), and 82 new samples were used to recalibrate prediction equations. New calibration equations obtained were validated with 18 independent samples not included in the calibration process.

\section{RESULTS AND DISCUSSION}

Table 1 shows the characteristics of the sample sets used in the study. Chemical analysis indicated that the calibration and validation sets covered similar ranges for each component, represented the variability that exist in the predicted samples.

The optimal calibration equation for semi-exotic maize stover samples was obtained using seven terms for NDF content and six terms for IVDMD. In this study the calibration equation for NDF content used the reflectance at wavelengths $1759,1778,1982,2100,2230,2270$ and $2336 \mathrm{~nm}$, and the primary wavelengths selected were 1778 and 1759 and $2336 \mathrm{~nm}$ (Table 2). These two wavelengths have been selected previously for the prediction of acid detergent fibre, crude protein and IVDMD in whole-plant maize forage (Valdes et al., 1990). It is also important to try to assign a chemical meaning to the wavelengths 
TABLE 1

Chemical composition of the semi-exotic maize stover samples used in NIRS analysis, \%

\begin{tabular}{|c|c|c|c|c|c|c|c|c|}
\hline \multirow[b]{2}{*}{ Component } & \multicolumn{4}{|c|}{ Calibration } & \multicolumn{4}{|c|}{ Validation } \\
\hline & $\mathrm{n}$ & range & mean & SD & $\mathrm{n}$ & range & mean & SD \\
\hline NDF & 162 & $59.85-76.35$ & 68.17 & 3.29 & 18 & $61.44-74.00$ & 69.00 & 3.42 \\
\hline IVDMD & 162 & $29.77-60.10$ & 44.73 & 6.94 & 18 & $33.46-55.76$ & 41.08 & 6.26 \\
\hline
\end{tabular}

TABLE 2

NIRS calibration statistics for neutral detergent fibre (NDF) and in vitro dry matter digestibility (IVDMD) in semi-exotic maize stover samples

\begin{tabular}{lcccccccccc}
\hline & & \multicolumn{8}{c}{ Wavelength, $\mathrm{nm}^{4}$} \\
\cline { 5 - 10 } Component & $\mathrm{R}^{1}$ & $\mathrm{SEC}^{2}$ & $\mathrm{CCV}^{3}$ & 1 & 2 & 3 & 4 & 5 & 6 & 7 \\
\hline NDF & 0.92 & 1.30 & 1.89 & 1778 & 1759 & 1982 & 2100 & 2336 & 2270 & 2230 \\
IVDMD & 0.93 & 2.56 & 5.72 & 2230 & 2208 & 2310 & 1778 & 1759 & 2336 \\
\hline
\end{tabular}

${ }^{1} \mathrm{R}$, coefficient of multiple correlation

${ }^{2}$ SEC, standard error of calibration

${ }^{3} \mathrm{CCV}$, calibration coefficient of variation

${ }^{4}$ filters in order of importance according to the size of the T-test

selected by NIRS. Osborne and Fear (1986) reported that the absorption band at $1759 \mathrm{~nm}$ was due to the first overtone stretching vibrations of $\mathrm{C}-\mathrm{H}$ bonds and $1778 \mathrm{~nm}$ band to hemicellulose. The $1600-1800 \mathrm{~nm}$ area are sensitive to primary and tertiary overtones of $\mathrm{C}-\mathrm{H}$ deformations and overtones of $\mathrm{N}-\mathrm{H}, \mathrm{C}-\mathrm{H}$, and $\mathrm{C}=\mathrm{O}$ (Clark and Lamb, 1991).

The other wavelengths selected in the NDF equation were between 2100 and $2300 \mathrm{~nm}$. The $2200-2300 \mathrm{~nm}$ area is associated primarily with C-H groups which are related to fibre (Clark and Lamb, 1991).

The calibration equation for IVDMD used the reflectance at wavelengths 1759, $1778,2208,2230,2310$ and $2336 \mathrm{~nm}$ and the first two wavelengths selected were 2230 and $2208 \mathrm{~nm}$. Some of the wavelengths have been previously selected in the prediction of IVDMD in whole-plant maize forage by the Tilley and Terry method (Valdes et al., 1987b) and by the pepsin-cellulase technique (Valdes et al., 1990). Clark and Lamb (1991) observed the frequency distribution of wavelength selection in studies on legumes, grasses and mixtures to measure digestibility (in vitro or in vivo) and the predominant wavelengths were $1600-1900 \mathrm{~nm}$ and $2200-2300 \mathrm{~nm}$. These regions are related to the more fibrous portion of plant material and the lignin content. Therefore, these regions of the NIRS spectrum are important both in the prediction of lignin content and in the prediction of digestibility (in vitro, in sacco or in vivo). The $1650-1700 \mathrm{~nm}$ region of the spectrum has been widely associated with digestibility equations (Marten et al., 1988). 
The values for the multiple correlation coeffcients and the standard error of calibration (SEC) were in general satisfactory and comparable with those reported by other workers using NIRS in maize forage to determine: in vitro digestible organic matter (Melchinger et al., 1986; Deinum and Struik, 1989; Zimmer et al., 1990), in vitro dry matter digestibility (Valdes et al., 1990) and NDF (Deinum and Struik, 1989; Zimmer et al., 1990).

Another criteria for determining the suitability of a calibration is the calibration coeffcient of variation $(\mathrm{CCV})$ as a percentage, the ratio of the standard error to the mean of the constituent values times 100 . Good calibrations have a CCV of $10 \%$ or less and the most robust calibrations will have $5 \%$ or less (McClure, 1994). The CCV obtain in semi-exotic maize forage was $1.89 \%$ for NDF and $5.72 \%$ for IVDMD.

The statistical results from linear regression analysis comparing those predicted from NIRS analysis are shown in Table 3 . The correlation coefficients obtained were 0.95 for NDF and 0.90 for IVDMD and the mean bias was near zero. The standard error of prediction (SEP) was comparable to SEC or even smaller. This may be explained by the fact that the SEP includes, as well as the error associated with wet chemica! analysis, the error associated with the NIRS

TABLE 3

Validation statistics for NIRS determination of chemical composition of semi-exotic maize stover

\begin{tabular}{lcccc}
\hline Component & $r^{\prime}$ & SEP $^{2}$ & Bias & Slope \\
\hline NDF & 0.95 & 1.75 & -0.09 & 1.168 \\
IVDMD & 0.90 & 3.35 & -0.69 & 1.222 \\
\hline
\end{tabular}

${ }^{1} \mathrm{r}$ - correlaticn coefficient

${ }^{2}$ SEP - standard error of prediction

equipment (Holechek et al., 1982). However the SEP did not exceed the SEC by $33 \%$ as suggested by Shenk et al. (1981). Melchinger et al. (1986) and Zimmer et al. (1990) also obtained in maize stover SEP comparable to SEC or even smaller than the SEC in some parameters. The standard error, slope and bias values of selected equations indicated that NDF and IVDMD (by the enzymatic method) were estimated acceptably in semi-exotic stover.

\section{CONCLUSIONS}

The results obtained showed sufficient accuracy in the predictions of cell-wall content and dry matter digestibility of semi-exotic maize stover, to be used in plant breeding programme. 


\section{REFERENCES}

Albanell E., Plaixats J., Caja G., 1993. Determination of chemical composition of carob pods by near-infrared reflectance spectroscopy. J. Sci. Food Agric. 63, 309-312

Albanell E., Plaixats J., Ferret A., Bosch L., Casanas F., 1995. Evaluation of near infrared reflectance spectroscopy for predicting stover quality trait in semi-exotic populations of maize. J. Sci. Food Agric. 69, 269-273

Aufrère J., 1982. Etude de la prévision de la digestibilité des fourrages par un methode enzymatique. Ann. Zootech. 31, 111-130

Clark D.H., Lamb R.C., 1991. Near infrared reflectance spectroscopy: A survey of wavelength selection to determine dry matter digestibility. J. Dairy Sci. 74, 2200-2205

Deinum B., Bakker J.J., 1981. Genetic differences in digestibility of forage maize hybrids. Neth. J. Agric. Sci. 29, 92-98

Deinum B., Struik P.C., 1989. Genetic variation in digestibility of forage maize (Zea mays L.) and its estimation by near infrared reflectance spectroscopy (NIRS). An analysis. Euphytica, 42, 89-98

Goering H.K., Van Soest P.J., 1970. Forage Fibre Analysis. Agriculture Handbook N 379 . ARS, USDA, Washington, DC, pp. 20

Holechek J.L., Shenk J.S., Vavra M., Arthum D., 1982. Prediction of forage quality using near infrared reflectance spectroscopy on oesophageal fistula samples from cattle on mountain range. J. Anim. Sci. 55, 971-975

Hunt C.W., Kezar W., Vinande R., 1992. Yield, chemical composition, and ruminal fermentability of corn whole plant, ear, and stover as affected by hybrid. J. Prod. Agric. 5, 286-290

Marten G.C., Halgerson J.L., Sleper D.A., 1988. Near infrared reflectance spectroscopy evaluation of ruminal fermentation and cellulose digestion of diverse forages. Crop Sci. 28, 163-167

McClure W.F., 1994. Near-infrared spectroscopy. In: R.H. Wilson (Editor). Spectroscopic techniques for food analysis. VCH Publishers, Cambridge (UK), pp. 13-57

Melchinger A.E., Schmidt G.A., Geiger H.H., 1986. Evaluation of near infrared reflectance spectroscopy for predicting grain and stover quality traits in maize. Plant Breeding, 97, 20-29

Norris K.H., Barnes R.F., Moore J.E., Shenk J.S., 1976. Predicting forage quality by infrared reflectance spectroscopy. J. Anim. Sci., 43, 889-897

Osborne B.G., Fearn T., 1986. Near Infrared Spectroscopy in Food Analysis. Longman Scientific and Technical, Harlow (UK), pp. 200

Pinter L., Hunter R.B., Szabo J., 1986. Near infrared technique as a tool for investigating corn silage (Zea mays L.) quality. Maydica, 31, 295-305

Shenk J.S., Landa I., Hoover M.R., Westerhaus M.O., 1981. Description and evaluation of a near infrared reflectance spectro-computer for forage and grain analysis. Crop Sci. 21, 355-358

Valdes E.V., Hunter R.B., Pinter L.,1987a. Determination of quality parameters by near infrared reflectance spectroscopy in whole-plant corn silage. Can. J. Plant. Sci. 67, 747-754

Valdes E.V., Hunter R.B., Jones G.E., 1987b. Comparison of near infrared calibrations for estimating in vitro digestibility in whole-plant corn hybrids. Can. J. Anim. Sci. 67, 557-562

Valdes E.V., Jones G.E., Hoekstra G.J., 1990. Effect of growing year and application of a multi-year calibration for predicting parameters by near infrared reflectance spectroscopy in whole-plant corn forage. Can. J. Plant Sci. 70, 747-755

Zimmer E., Gurrath P.A., Paul C., Dhillon B.S., Pollmer W.G., Klein D., 1990. Near infrared reflectance spectroscopy analysis of digestibility traits of maize stover. Euphytica, 48, 7381 


\section{STRESZCZENIE}

Zastosowanie metody NIRS do prognozowania wartości pokarmowej łodyg kukurydzianych

Badano przydatność metody NIRS do oznaczenia zawartości NDF i strawności in vitro SM jako wskaźników jakości łodyg kukurydzianych. Próby kukurydzy pochodziły ze skrzyżowania odmiany Across 8443 La Plata z inbredem Mo 17. Oznaczenia prowadzono na aparaturze InfraAnalyzer 450 (Bran + Luebbe).

Równania kalibracyjne obliczono metodą wielokrotnej regresji liniowej ze 162 próbek i zweryfikowanych na podstawie dodatkowych 18 prób. Współczynniki wielokrotnej korelacji wynosiły 0,92 dla zawartości NDF i 0,93 dla strawności SM, a błąd standardowy kalibracji wynosił odpowiednio 1,30 i 2,56 .

Otrzymane wyniki wskazują, że dokładność określania zawartości NDF i strawnej SM w łodygach kukurydzianych jest wystarczająca dla hodowli roślin. 